\title{
The Elements of Behavioral Control in Facilitating the Acceptance of Technological Innovation on Malaysia On-line Government Services
}

\author{
Maizatul Haizan Mahbob (Corresponding author) \\ School of Media and Communication Studies \\ Universiti Kebangsaan Malaysia, UKM, 43600 Bangi, Selangor, Malaysia \\ Tel: 60-3-8921-5464 E-mail:maiz@ukm.my \\ Wan Idros Wan Sulaiman \\ School of Media and Communication Studies \\ Universiti Kebangsaan Malaysia, UKM, 43600 Bangi, Selangor, Malaysia \\ Tel: 60-3-8921-3588 E-mail: wiws@ukm.my \\ Wan Amizah Wan Mahmud \\ School of Media and Communication Studies \\ Universiti Kebangsaan Malaysia, UKM, 43600 Bangi, Selangor, Malaysia
}

Tel: 60-3-8921-4209 E-mail: wan_amizah@ukm.my

Normah Mustaffa

School of Media and Communication Studies

Universiti Kebangsaan Malaysia, UKM, 43600 Bangi, Selangor, Malaysia

Tel: 60-3-8921-4388Ｅ-mail: normahm@ukm.my

Mohd Yusof Abdullah

School of Media and Communication Studies

Universiti Kebangsaan Malaysia, UKM, 43600 Bangi, Selangor, Malaysia

Tel: 60-3-8921-5809 E-mail: myusof@ukm.my

Received: March 1, $2012 \quad$ Accepted: March 13, $2012 \quad$ Published: April 16, 2012

doi:10.5539/ass.v8n5p125 URL: http://dx.doi.org/10.5539/ass.v8n5p125

This project is funded by Ministry of Higher Education Malaysia (FRGS/1/2011/SS/UKM/03/8).

\begin{abstract}
This article discusses the elements of behavioral control in facilitating the intention of an execution of a particular action. There are two elements to be focused namely self efficacy and facilitating condition. To identify the extent to which behavioral control and the two elements influence one's actions, a survey of 232 respondents was conducted on residents in the Klang Valley. By using SEM analysis, a model of the acceptance of innovation (e-service) was formed. Focusing specially on behavioral control, the model found that this factor has a significant influence on adoption behavior $(\beta=.67 ; \mathrm{p}<.01)$. Elements of self-efficacy and facilitating condition have a significant influence on behavioral control, with self-efficacy having a greater influence $(\beta$ $=.76 ; \mathrm{p}<.01)$ on behavioral control compared to facilitating condition $(\beta=.16 ; \mathrm{p}<.01)$.
\end{abstract}

Keywords: Innovation acceptance, Technological innovation, Behavioral control, E-Government, E-service 


\section{Introduction}

Research related to the acceptance of technological innovation which mostly focus on how and why individuals use information technology, have been conducted over the past two decades. Intent to accept and use of technology depends on how the technology will benefit them, ease of use and facilitates them to use. Thus the transition towards a desired behavior involves the use of effective communication in order to influence the receiver to do what is desired by the sender. This is important especially when it comes to public policy. The way policies are being advocated either by individuals or groups from government agencies, private sector and non-governmental organizations (NGOs) are essential in achieving policy objectives.

Communication can be seen in several essential context such as in the context of intra-personal (how individuals process information, interpersonal (how interactions between individuals affect each other), group (how the dynamics of communication exists among many individuals), formal and informal organizations (how communication exist and function in the space of organization), and finally in the context of community or society, which is focused on how communications develop and change the agenda of important issues (Breslow \& Cengage, 2002).

Acceptance of technological innovation through the use of e-services provided by the government involves the context of intra-personal communication, interpersonal, group and community. This is according to the nature and role of the policy itself that involves the use of communication and a variety of multilateral contexts. Through a particular medium, the messages are expected to change perceptions and behavioral intentions and use.

\section{Behavioral Control Factor as a Facilitating Agent of Acceptance}

There are many factors associated with acceptance of an innovation or new ideas. Hu et.al (1999) and Chau \& Hu (2002) divide these factors into three main context which is individual, technological and implementation context. Individual context is the perception and evaluation of the individual about the technology (Chau \& Hu 2002). From previous studies, predictor variables that can be classified in terms of individual contexts are attitudes (Fishbein \& Ajzen 1975; Ajzen 1991; Schaper \& Pervan 2006; Chau \& Hu, 2001; Venkatesh et.al 2000; Bhattacherjee 2000), intrinsic motivation (Davis et.al 1992), self efficacy (Bandura, 1986; Compeau \& Higgins 1995; Schaper \& Pervan 2006; Taylor \& Todd 1995; Bhattecherjee 2000), anxiety (Compeau \& Higgins 1995, Schaper \& Pervan, 2006), playfulness (Chien \& Shu 2006), trustworthiness (Pierre Gagnon et.al 2003; Ing \& Jian 2005; Triandis 1980; Feng et.al 2007 ; Yusof et.al 2005), risk (Gefen et.al 2002; Stone \& Gronhaug 1993), the perception of cost (Feng et.al 2007; Luarn \& Lin 2005), habit (Triandis 1980; Pierre Gagnon et.al 2003) and affective (Triandis 1980; Bergeron et.al 1995; Pierre Gagnon et.al 2003; Thompson et.al 1991, Compeau \& Higgins 1995).

Meanwhile, technological context refers to the characteristics of the technology itself. According to $\mathrm{Chau} \& \mathrm{Hu}$ (2002), to be accepted by the individuals, the technology must be at least useful to carry their work. Technology and instruments used should not be complex. A person who has a positive perception about ease of use, can contribute to the development and strengthening a positive attitude towards the use of technology, and thereby strengthen the intention to accept technology. Predictors of behavioral intention based on previous studies that can be grouped into the context of technology are perceived usefulness/ performance expectation/ benefits relative (Davis 1989; Davis et.al 1989; Venkatesh \& Davis 2000; Croteau \& Vieru 2002; Schaper \& Pervan 2006; Rogers 1995; Mohd Sobhi et.al 2011), perceived ease of use/complexity (Davis 1989; Davis et.al 1989; Venkatesh \& Davis 2000; Croteau \& Vieru 2002; Rogers 1995; Schaper \& Pervan 2006; Thompson et.al 1991; Mohd Sobhi et.al 2011), impact perception (Succi and Walter 1999), quality of output (Venkatesh \& Davis, 2002), long-term effect (Thompson et.al 1991) the expected results (Venkatesh \& Davis, 2002; Compeau \& Higgins, 1995), perceptions of the consequences (Bergeron et.al 1985; Pierre Gagnon et.al 2003; Triandis 1980), and extrinsic motivation (Davis et al. al 1992).

Next, is environmental context. It refers to a specific setting in which the targeted technology is to be implemented (Chau \& $\mathrm{Hu}$ 2002). Predictor variables on innovation acceptance in the context of environment are social influences/social norms/subjective norm (Hu et.al 1999; Hu \& Chau 1999; Croteau \& Vieru 2002; Schaper \& Pervan 2006; Pierre Gagnon et.al 2003; Fishbein \& Ajzen 1975; Ajzen 1991; Chau \& Hu 2002; Venkatesh et.al 2000; Bhattacherjee 2000; Chia \& Ting 2005), facilitating condition (Triandis 1980; Bandura, 1986; Taylor \& Todd 1995; Bhattacherjee 2000), perceived behavioral control (Ajzen 1991; Chau \& Hu, 2001; Liao et.al 1999; Taylor \& Todd 1995; Venkatesh et.al 2000; Bhattacherjee 2000; Shin et.al 2005), visibility (Rogers 1995), images (Croteau \& Vieru 2002; Venkatesh \& Davis, 2002; Rogers, 1995), compatibility (Rogers 1995; Schaper \& Pervan 2006; Taylor \& Todd 1995; Mathieson 1991) and the credibility of information (Mohd Sobhi et.al 2011). 
This paper however, focusses on the factors of the behavioral control by Ajzen (1991). Behavioral control is the perception of the easiness or hardness in performing a behavior depending on the resources and opportunities available. This is a decisive factor to innovation acceptance behavior other than the intention. Behavioral control beliefs are based on past experience of the behavior, or are influenced by both sources of information about behavior such as experience from a friend, or by other factors that increase or reduce the perception of the difficulty to perform the behavior under consideration. This factor is taken from the original Theory of Planned Behavior (TPB) presented by Ajzen (1991). Taylor \& Todd (1995) then decomposed this factor into two specific beliefs, self efficacy and facilitating condition. The purpose of the decomposition of TPB is to get a higher explanatory power, thus providing a comprehensive understanding of the acceptance of innovation.

Self-efficacy is an assessment of one's ability to use technology such as computers in performing a task. Facilitating condition is the thrust of the environment that supports individuals' actions. If self efficacy focuses on the internal notion of the individual, facilitating condition focuses on the external notion. Both of these beliefs seem to influence the perception of behavioral control in accepting an innovation. The influence of self efficacy on the behavioral control can be seen through the study of Taylor \& Todd (1995); Lin (2007); Hung \& Chang (2004); Hsu et.al (2006) and Hung et.al (2005). This means that self-efficacy influences the control of a person to perform a behavior.

Facilitating condition associated with resources such as time, cost, and opportunity is also a significant determinant of behavioral control (Taylor \& Todd 1995). This finding is supported by Hung et.al (2005) who studied the acceptance of the e-filing system. However, this significant relationship only applies to individuals who use the system.

Behavioral control factors that consist of self efficacy and facilitating condition, are among the main factors in several models and theories explaining the influence of these factors on innovation acceptance. Among them are the Theory of Interpersonal Behavior - TIB (Triandis, 1980), Theory of Planned Behavior - TPB) (Ajzen, 1991), Model of PC Utilizations - MPCU (Thompson, Higgins \& Howell, 1991), Decomposed Theory of Planned Behavior - DTPB ) (Taylor \& Todd, 1995) and the Model of Unified Theory of Acceptance and Use of Technology - UTAUT (Venkatesh et.al 2003).

The performance of an adoption behavior usually depends on the availability of resources both internal and external drivers such as the ability of individuals, opportunities and resources such as time, money, expertise and cooperation of others. These factors, represent an actual control over the behavior. Individuals with an opportunity and resources (external capabilities), abilities (internal capabilities) and intention (motivation) to perform actions or a specific behavior, often successful with the acceptance. Lack of these resources, will be obstacles to the usage and restrain one's intention. However, the existence of these resources, not necessarily encourage the use of IT (Taylor \& Todd 1995).

\section{Research Methodology}

Survey method with cluster and purposive sampling is used in this study.The main areas in the Klang Valley; Klang, Shah Alam, Puchong, Selayang, Sungai Buloh, Bangi and Kajang have been selected as the main sample. A group of study was then reduced by taking a few settlements in accordance with the socioeconomic levels of low-cost housing, medium-cost housing, medium-luxury cost housing and luxury-cost housing. A total of 232 respondents aged 18 years and above who have used the on-line government services (e-service) were selected as subjects for the research. Data were then analyzed using Structural Equation Modeling (SEM). Although there are several predictor variables to identify the adoption behavior, but in the context of this article, the focus will only be on the behavioral control factor and its antecedent element that consists of self-efficacy and facilitating condition.

\section{Results and Discussion}

From 232 respondents surveyed, the demographic profile shows that women (52.2\%) use the e-service more than men. 51.3\% aged 36 years and above and 54\% work in the private sector. Majority of the respondents (72.4\%) have High School certificates (SPM and STPM) and Diploma. While their income (67\%) falls between the range of RM 4000 and below.

As described by Rogers (2003), before innovation is accepted, individuals should undergo the diffusion process that consists of five stages, namely knowledge, persuasion, decision, implementation and confirmation. Malaysia is no exception in adopting this diffusion process. The government, private sectors and non govermental organisations have shown great interest and commitment in providing "knowledge" to the community by disseminating it via (through) electronic and print media. In this study, electronic media (81.9\%) is the main source of information, followed closely by print media( $71.1 \%)$. Other sources ranging from government agencies, 
peers/spouse and NGOs have also contributed to the respondent's source of knowledge with $39.7 \%, 33.6 \%$ and $11.6 \%$ respectively. This means that variety of sources play a role in providing exposure, knowledge and awareness to the community about the innovation of the on-line government services.

These sources also act as an agent of "persuasion". When the government announces the benefits that can be gained by accepting this innovation such as obtaining fast services, cost and time effectiveness and performance, it will not only increase the productivity of the people, but also to help develop the country.

These two stages, knowledge and persuasion are important in creating "decision" to accept innovation. Based on the data, almost all respondents $(96.1 \%)$ who use the system of e-services, are aware of the existence of this innovation and recognize that innovation is beneficial to them. Thus they "implement" the decision to accept and use the system of on-line services such as paying utility bills, traffic summons, taxes and compound of local authorities. Respondents also "confirm" their decisions when most of them (82\%) stated that they use e-services more than once.

Hence, what motivates the respondents to receive and use the innovation? One of the factors was the behavioral control. Before government advocates the people about the services provided, it has carefully planned the development of ICT infrastructure to enable e-government being implemented efficiently. Plans have been made since 1996 in the Seventh Malaysia Plan (Rais \& Nazariah, 2003). Ongoing commitment from the government has now positioned Malaysia at number eleven for the year 2009 in terms of e-government development at the global level. This is a rating index survey conducted by the Brooking Institute in the United States (The Malay Mail, 2010). Government's efforts can be divided into two forms, firstly, associated with facilitating condition, and secondly, related to self efficacy. Both of these beliefs are the element under the behavioral control factor (Taylor \& Todd, 1995).

Model 1 of the acceptance of on-line government services, indicating factors of behavioral control, subjective norms and attitude accounted for $77 \%$ variance on intention to use e-services, while conforming to the actual usage contributed by all of these factors is by $26 \%$. While the influence of behavioral control on actual behavior is greater $(\beta=.67 ; \mathrm{p}<.01)$ than the intention to accept these services $(\beta=.38 ; \mathrm{p}<.01)$. It means that behavioral control is important in encouraging individuals to accept an innovation. Hence, the findings support with what was stated by Ajzen (1991) that without the element of behavioral control, the intention is not necessarily turn into action. To ensure that action occurs, the intention must be buttressed by the behavioral control. Hence this factor is actually controlling everyone's action.

Between the two elements that underlie the behavioral control factor, the government initially focused more on facilitating condition, followed by self efficacy. One of the things that can be linked to the facilitating condition is the ICT infrastructures developed by the government. Through the Ministry of Information, Communication and Culture (MICC), the Universal Service Provision (USP) has been implemented, to provide basic facilities such as mobile communications, computer and Internet access. A total of 1169 libraries and rural clinics throughout the country have been provided by this USP to enable rural communities to access information (Aspirasi Digital, 2009). Ease of access has led to the establishment of tele-centers or e-community center developed by either the federal government, state governments or the private sector. To date (2010), there are 1670 tele-centers throughout the country (Norizan et.al, 2007). The government is also implementing a campaign of one house one computer to facilitate computer ownership, tax relief on the purchase of computers, broadband subscription fee reduction, and free notebook of one million units to the less fortunate. These are all factors that lead to the facilitating condition to encourage adoption of innovation.

Simultaneously, the government is also developing self efficacy and confidence of the people via programs related to information technology (IT) so that they can use the innovation effectively. For urban communities, the government has gradually mandatorates ( meaning?) the utilization of on-line services, particularly in the public service. From the recorded time of arrival, till the evaluation of employees, all civil servants have been trained to be able to use the on-line services. When they are familiar with this situation, it makes it easier for the government to offer more services on-line. People are also encouraged to use the on-line system to get application forms or services that they want directly on-line. For rural communities, instructors with IT skills are sent to train rural people on the usage of computers and the Internet. This is one of a methods of bridging the digital divide between regions. Among the programs created to improve the self efficacy of citizens, particularly the rural population is Bestari.com (State of Terengganu info center and ICT training and learning center for rural citizens), Mobile Internet Unit (offering) training on ICT skills to rural area students, Bridging Digital Divide Initiative (to bridge digital divide and give awareness about ICT usefulness), Portal NurIta (training on computer 
literacy among women especially single mother), Warga Emas Network (providing education and computer access to senior citizens to enhance their IT knowledge) and many more.

Based on model 1, the two elements of belief in behavioral control factor have an influence and direct relations with behavioral control. However, the influence of self-efficacy $(\beta=.76 ; p<.01)$ was significantly greater on behavioral control compared to facilitating condition $(\beta=.16 ; \mathrm{p}<.01)$. This indicates that self-efficacy is more important in order to induce a person to adopt innovation especially those related to technology. Although IT infrastructure was successfully developed, but if it is not followed by a willingness and ability of people to use it, the development will be not successful because will not achieve the intended results.

\section{Conclusion}

Intention to accept an innovation and the behavioral control factor need to go in parallel in order to achieve successful result of acceptance. Without these factors, the intention cannot be translated into action as expected. It is important to ensure that the behavioral factor such as campaigns and programs on e-services are perceived in a positive manner. To encourage a person to accept change, it is necessary to facilitate an external resources such as time, money, opportunity, and equipment, as well as internal resources such as awareness, ability and confidence. The contributions of these findings are to increase the effectiveness of the campaign/programs implemented by the government. Whatever programs involving innovation, the sole use of the media to educate and increase public awareness of action is not sufficient to move them to accept innovation. It has to be accompanied by the factor of behavioral control to make people willing and able to accept it.

\section{References}

Ajzen, I. (1991). The theory of planned behavior. Organizational Behavior and Human Decision Processes, 50(2), 179-211. http://dx.doi.org/10.1016/0749-5978(91)90020-T

Ajzen, I. (2005). Attitudes, Personality and Behavior. Berkshire, England: Open University Press.

Bandura, A. (1986). Social Foundations of Thought and Action: A Social Cognitive Theory. Englewood Cliffs, New Jersey: Prentice Hall.

Bergeron, F., Raymond, L., Rivard, S. \& Gara, S. (1995). Determinants of EIS use: Testing a behavioral model. Decision Support Systems, 14, 131-146. http://dx.doi.org/10.1016/0167-9236(94)00007-F

Bhattacherjee, A. (2000). Acceptance of e-commerce services: The case of electronic brokerages. IEEE Transactions on System, Man and Cybernetics. Systems and Humans, 20(4), 411-420.

Breslow, L. \& Cengage, G. (2002). Communication theory: Encyclopedia of public health. Retrieved 8 April, 2010, from: http://www.enotes.com/public_health_encyclopedia/comm_theory

Chau, P.Y.K. \& Hu, P.J.-H. (2001). Information technology acceptance by individual professionals: A model comparison approach. Decision Sciences, 32 (4), 699-719. http://dx.doi.org/10.1111/j.1540-5915.2001.tb00978.x

Chau, P.Y.K. \& Hu, P.J.-H. (2002). Investigating healthcare professionals' decisions to accept telemedicine technology: An empirical test of competing theories. Information Management Systems, 39, 297-311.

Chien-Huang Lin \& Shu-Fen Yu. (2006). Consumer adoption of the internet as a channel: The influence of driving and inhibiting factors. The Journal of American Academy of Business, 9(2), 112-117.

Compeau, D.R. \& Higgins, C. A. (1995). Computer self-efficacy: Development of a measure and initial test. MIS Quarterly, 19(2), 189-211. http://dx.doi.org/10.2307/249688

Croteau, A.-M. \& Vieru, D. (2002). Telemedicine adoption by different group of physicians. $35^{\text {th }}$ Hawaii International Conference on System Sciences. Maui, Hawaii: IEEE Computer Society.

Davis F. D. (1989). Perceived usefulness, perceived ease of use, and user acceptance of information technology. MIS Quarterly, 13(3), 319-339. http://dx.doi.org/10.2307/249008

Davis, F.D., Bagozzi, R.P., \& Warshaw, P.R. (1992). Extrinsic and intrinsic motivation to use computers in the workplace. Journal of Applied Social Psychology, 22, 1111-1132. http://dx.doi.org/10.1111/j.1559-1816.1992.tb00945.x

Feng Cheng Tung, Su Chao Chang \& Chi Min Chou. (2007). An extension of trust and TAM model with IDT in the adoption of the electronic logistics information system in HIS in the medical industry. International Journal of Medical Informatics. Article in Press.

Fishbein, M. \& Ajzen, I. (1975). Belief, Attitude, Intention and Behavior: An Introduction to Theory and Research. Reading, Massachussets: Addison-Wesley. 
Gefen, D., Pavlou, P.A., Warkentin, M. \& Rose, G.M. (2002). E-government adoption. Proceedings of The Eighth Americas Conference on Information Systems, 569-576.

Hsu Tsuen-Ho, Wang Yi-Sheng \& Wen Su-Chan. (2006). Using the decomposed theory of planned behavior to analyse consumer behavioral intention towards mobile text message coupons. Journal of Targeting, Measurement \& Analysis for Marketing, 14(4), 309-324. http://dx.doi.org/10.1057/palgrave.jt.5740191

Hu, P.J. \& Chau, P.Y.K. (1999). Physician acceptance of telemedicine technology: An empirical investigation. Top Health Information Management, 19(4), 20-35.

Hu, P.J., Chau, P.Y.K., Liu-Sheng, O.R., \& Tam, K.Y. (1999). Examining the technology acceptance model using physician acceptance of telemedicine technology. Journal of Management Information Systems, 16(2), 91-112.

Hung Shin Yuan, Chang Chia Ming \& Yu Ting Jing. (2005). Determinants of user acceptance of the e-government services: The case of online tax filing and payment system. Government Information Quarterly, 23(1), 97-122.

Ing Long Wu \& Jian Liang Chen. (2005). An extension of trust and TAM model with TPB in the initial adoption of on-line tax: An empirical study. International Journal Human Computer Studies, 62, 784-808. http://dx.doi.org/10.1016/j.ijhcs.2005.03.003

Liao, S., Shao, Y.P., Wang, H. \& Chen, A. (1999). The adoption of virtual banking: An empirical study. International Journal of Information Management, $19(1), \quad 63-74$. http://dx.doi.org/10.1016/S0268-4012(98)00047-4

Luarn, Pin \& Lin, Hsin-Hui. (2005). Toward an understanding of the behavioral intention to use mobile banking. Computers in Human Behavior, 21, 873-891. http://dx.doi.org/10.1016/j.chb.2004.03.003

Mathieson, K. (1991). Predicting user intentions: Comparing the technology acceptance model with the theory of planned behavior. Information Systems Research, 2(3), 173-191. http://dx.doi.org/10.1287/isre.2.3.173

Mohd Sobhi Ishak, Musa Abu Hassan, Siti Zobidah Omar, Jusang Bolong \& Zulkiple Abd Ghani. (2011). Kredibiliti maklumat sebagai faktor anteseden yang mempengaruhi tanggapan pengguna dalam model penerimagunaan maklumat berkaitan Islam di internet. International Conference on Media and Communication: Communication and Transformation: Progress and Paradox. 11-12 October 2011. Hotel Equatorial, Bangi-Putrajaya. Pusat Pengajian Media dan Komunikasi, UKM. Prosiding.

Mohd Yusof Hj.Abdullah, Mohd Azul Mohamad Salleh, Mohd Safar Hasim, Fuziah Kartini Hassan Basri, Arfah Yusof \& Mat Pauzi Abd Rahman. (2005). e-Kerajaan dan e-dagang: Isu kepercayaan dan keselamatan. Bengkel Membudayakan Masyarakat Jaringan: Cabaran dan Batasan. 16 Jun 2005. Pusat Pengajian Media dan Komunikasi, Universiti Kebangsaan Malaysia. Kertas Kerja.

Muhammad Rais Abdul Karim \& Nazariah Mohd Khalid. (2003). e-Government in Malaysia. Subang Jaya: Pelanduk Publications.

Norizan Abdul Razak, Mohd Zaki Ibrahim, Zaini Amir, Rosenni Din \& Kemboja Ismail. (2007). Seminar Merapatkan Jurang Digital: Inisiatif Malaysia. 10-11 Disember 2007. Berjaya Times Square Hotel \& Convention Centre, Kuala Lumpur. Pusat Kajian e-Komuniti, UKM. Prosiding.

Pierre-Gagnon, M., Godin, G., Gagne, C., Fortin, J., Lamothe, L., Rienharz, D. \& Cloutier, A. (2003). An adaptation of the theory of interpersonal behaviour to the study of telemedicine adoption by physicians. $\begin{array}{lllll}\text { International Journal of } & \text { Medical } & \text { Informatics, } & 71(2-3), & 103-115 .\end{array}$ http://dx.doi.org/10.1016/S1386-5056(03)00094-7

Rogers, E. (1995). Diffusion of Innovations ( $4^{\text {th }}$ ed.). New York: Free Press.

Schaper, L.K. \& Pervan, G.P. (2006). ICT and OTs: A model of information and communication technology acceptance and utilisation by occupational therapists. International Journal of Medical Informatics. In press, corrected proof.

Stone, R.N. \& Gronhaug, K. (1993). Perceived risk: Further considerations for the marketing disciplines. European Journal of Marketing, 27(3), 39-50. http://dx.doi.org/10.1108/03090569310026637

Succi, M.J. \& Walter, Z.D. (1999). Theory of user acceptance of information technologies: An examination of health care professionals. $32^{\text {nd }}$ Hawaii international Conference on System Sciences. Hawaii: IEEE Computer Society. 
Taylor, S. \& Todd, P.A. (1995). Understanding information technology usage: A test of competing models. Information Systems Research, 6(2), 144-176. http://dx.doi.org/10.1287/isre.6.2.144

The Malay Mail. (2010). (17 Mei 2010). Retrieved from: http://www.mmail.com.my/content/15662-malaysia-ranks-11-egovernment-implementation

Thompson, R.L. \& Higgins, C.A. \& Howell, J.M. (1991). Personal computing: Toward a conceptual model of utilization. MIS Quarterly, 15(1), 124-143. http://dx.doi.org/10.2307/249443

Triandis, H.C. (1980). Values, attitudes and interpersonal behavior. in M.M. Page (Ed), Nebraska Symposium on Motivation, 1979: Beliefs, Attitudes and Values. Lincoln: University of Nebraska Press.

Venkatesh, V. \& Davis, F.D. (2000). A theoretical extension of the technology acceptance model: Four longitudinal field studies. Management Science, 46(2), 186-204.

Venkatesh, V., Morris, M.G., Davis, G.B. \& Fred, D. (2003). User acceptance of information technology: Toward a unified view. MIS Quarterly, 27(3), 425-478. http://dx.doi.org/10.1287/mnsc.46.2.186.11926

-----------. (2009). Aspirasi Digital. Majalah Dwibulanan Kementerian Penerangan Komunikasi dan Kebudayaan Malaysia.

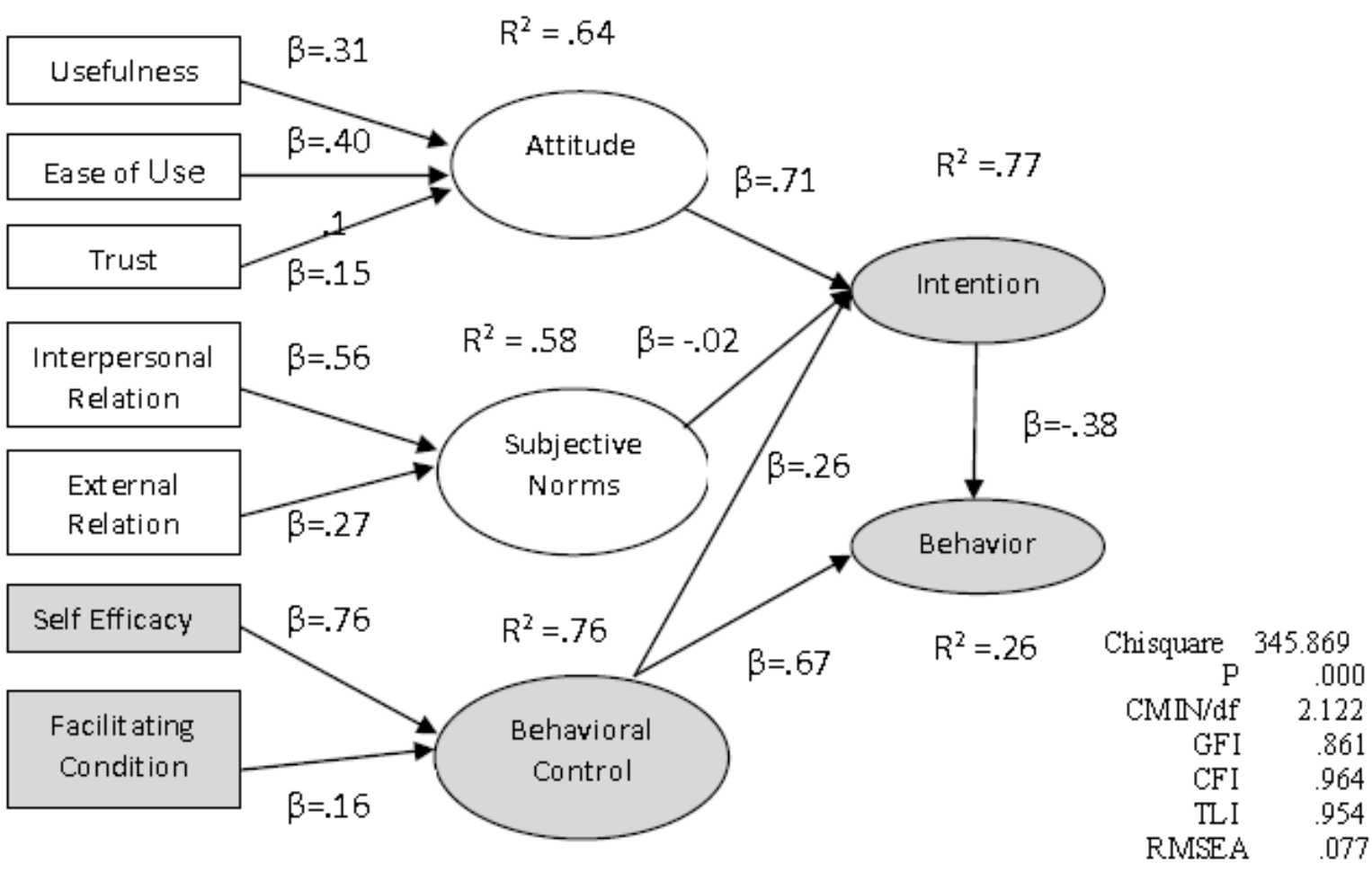

Model 1. The acceptance of on-line government services among the population in the Klang Valley 